Relations industrielles

Industrial Relations

\title{
Manpower Policies for Youth, by Eli Cohen and Louise Kapp, Columbia University Press, New York and London, 1966, 152 pp.
}

\section{Pierre Dionne}

Volume 23, numéro 1, 1968

URI : https://id.erudit.org/iderudit/027885ar

DOI : https://doi.org/10.7202/027885ar

Aller au sommaire du numéro

Éditeur(s)

Département des relations industrielles de l'Université Laval

ISSN

0034-379X (imprimé)

1703-8138 (numérique)

Découvrir la revue

Citer ce compte rendu

Dionne, P. (1968). Compte rendu de [Manpower Policies for Youth, by Eli Cohen and Louise Kapp, Columbia University Press, New York and London, 1966, 152 pp.] Relations industrielles / Industrial Relations, 23(1), 185-185.

https://doi.org/10.7202/027885ar

Tous droits réservés @ C Département des relations industrielles de l'Université Laval, 1968
Ce document est protégé par la loi sur le droit d'auteur. L'utilisation des services d'Érudit (y compris la reproduction) est assujettie à sa politique d'utilisation que vous pouvez consulter en ligne.

https://apropos.erudit.org/fr/usagers/politique-dutilisation/ 
Manpower Policies for Youth, by Eli Cohen and Louise Kapp, Columbio University Press, New York and London, 1966, 152 pp.

This will be an invaluable book for all those who want to have a better understanding of why job problems are mounting among low-income youth and the steps that must ba token to settle them.

Drown from papers presented at a symposium held by the National Committee on Employment of Youth, this book brings together the diverse views of leoding persons from the government, the universities, industry, labor and other groups. The range of their proposals makes it clear how many factors, social and economic, have combined to bring about today's youth unemployment crisis. And according to most of the contributors, the crisis will continue until we opply for more basic and strenuous measures than have yet been instituted.

Among the wide variety of proposals put forward are policies to vastly improve education in poverty-stricken areas, to make training more relevant to todoy's job market to motivate private industry to hire more young people, to expand the government's role both as a labor market exchange and os a creator of jobs in the public sector, and to establish new forms of work and income that will compensate for the jobdisplacing effects of automation and cybernetion.

There are fourteen papers in this volume "New Approached to Financing Education and Training 》, "Whose Existential Crisis? 》, "Planning for Leisurs", "The U.S. Empioyment Service in Perspective ", "JobCrecting Potentials in the Public Sector «Guidelines for Improved Public Policy », and "Which Goals for the Future? " are just same of the titles. Many new ideas are explored in these papers.

The Committee is a nonprofit, non-governmental organization concentrating exclusively on the obstacles young people face in preparing for and finding suitable work Through its programs of national and local consultation, research, training, and public information, it seeks to improve education and training and to provide greater job opportunities for America's youth.

\section{Pierre DIONNE}

Le placement des travailleurs âgés, Division des Affaires sociales de I'O.C.D.E., Paris, 1967, $100 \mathrm{pp}$
Cet ouvrage est destiné à fournir aux fonctionnaires des services de placement chargés de trouver des emplois pour les personnes âgées, les techniques susceptibles $\mathrm{d}^{\prime}$ améliorer leurs possibilités de servir à la fois le candidat et l'employeur. $Y$ sont mis en évidence: les moyens spéciaux propres à ajuster les techniques traditionnelles de placement, telles que les conseils professionnels, les tests, la formation et la recherche des places, pour qu'elles soient plus efficaces dans la promotion de l'emploi des personnes âgées. Les méthodes pour encourager ces possibilités de placement sont décrites en détail.

Les deux premiers chapitres intitulés "La récupération des aptitudes inutilisées 》 et « Programmes de propagande et d'éducation " ont un caractère descriptif. On cherche à cerner les problèmes réels qu'affrontent les chômeurs âgés, à expliciter les raisons de leur état, et à définir les services qui peuvent les aider à en sortir et à retourner un emploi rémunérateur.

Le troisième chapitre établit la distinction entre un service normal et un service spécial de placement pour les travailleurs âgés.

Les trois chapitres suivants tentent de répondre à une question fondamentale du problème: Comment accroître les possibilités d'emploi du travailleur? II s'agit donc de l'élaboration d'un programme de formation et de réadaptation professionnelles adéquat et de ses problèmes d'application.

Le dernier chapitre renferme des renseignements essentiels sur la coopération avec les employeurs pour trouver des emplois.

Les organismes publics et privés de placement y trouveront une analyse particulièrement utile, surtout du fait que le rapport contient des illustrations détaillées sur les méthodes propres à faire progresser cette action en faveur des travailleurs âgés.

\section{Pierre DIONNE}

\section{Du Tripartisme à l'Organisation Internatio-} nale du Travail, par Eliane Vogel-Polsky, Etudes du Centre national de Sociologie du droit social, Editions de l'Institut de Sociologie de I'Université de Bruxelles, 1966, 352 pages.

Le présent ouvrage se propose d'étudier les problèmes fondamentaux d'ordre juridique et technique, posés par l'application du Tripartisme au sein de l'Organisation Internationale 